\title{
IN VITRO MATURATION OF BOVINE GRANULOSA CELLS FOR STEROID HORMONE PRODUCTION
}

\author{
MADURACIÓN IN VITRO DE CÉLULAS DE LA GRANULOSA BOVINA PARA LA \\ PRODUCCIÓN DE HORMONAS ESTEROIDES
}

\author{
Smith, O.F. ${ }^{1 *}$, Ogunsola, A.A. ${ }^{1}$, Ladokun, A.O. ${ }^{1}$ and Ajadi, T.A. ${ }^{2}$ \\ 1'Department of Animal Physiology. University of Agriculture. Abeokuta. Nigeria. *smith_olusiji@yahoo.com \\ ${ }^{2}$ Department of Public Health and Reproduction. University of Agriculture. Abeokuta. Nigeria.
}

\section{AdDitiONAL KEYWORDS \\ Cell culture. Culture medium.}

\section{SUMMARY}

This study aimed to evaluate the effects of preincubated granulosa cells on in vitro maturation and steroid hormones production in cows. Granulosa cells from the ovaries were cultured using the modified M-199 with Earle's salts. $1 \%$ bovine serum albumin was added and $5 \%$ fetal calf serum. Also $0.8 \%$ of antibiotics was also included. Cultures were incubated at $37^{\circ} \mathrm{C}$ in a $95 \%$ air and $100 \%$ relative humidity. There were significant differences among values of progesterone and estradiol concentration obtained for levels of inclusion of FSH and LH. It can be concluded that there is necessity for supplementation of hormones in culture medium for bovine IVM.

\section{RESUMEN}

Se evaluó el efecto de células de granulosa preincubadas sobre la maduración in vitro y producción de hormonas esteroides en vacas. Las células de granulosa de los ovarios fueron cultivadas empleando el M-199 modificado con sales de Earle. Se añadió 1\% de albúmina de suero bovino y $5 \%$ de suero fetal de ternero. También se incluyó un $0,8 \%$ de antibióticos. Los cultivos fueron incubados a $37^{\circ} \mathrm{C}$ con $95 \%$ de aire y $100 \%$ de humedad relativa. Se registraron diferencias significativas entre las concentraciones de progesterona y estradiol obtenidas con los niveles de inclsuión de FSH y LH. Puede concluirse que es necesario suplementar con hormonas el medio de cultivo para IVM en bovinos.

Recibido: 19-3-10. Aceptado: 24-6-10.

\author{
Palabras clave adicionales \\ Cultivo celular. Medio de cultivo.
}

\section{INTRODUCTION}

The ovary of the cattle is a complex endocrine gland responsible for production of sex steroids and is the source of fertilizable ova for reproduction. The ovary possesses two primary steroidogenic cell types. The theca cells are responsible for androgen synthesis while the granulosa cells are responsible for conversion of androgens to estrogens as well as progesterone synthesis. These cells undergo a transformation in the luteal phase of the menstrual cycle, converting them from estrogen producing, to predominantly progesterone producing cells. Estradiol is produced by granulosa cell aromatisation of androgens secreted by the theca cells (Fortune, 1994). Estradiol synergises with the gonadotrophins to regulate the expression of $\mathrm{FSH}$ and $\mathrm{LH}$ receptors on granulosa cells, which are important developmental checkpoints in the lifespan of the follicle at recruitment and selection respectively (Dierich et al., 1998, Ma et al., 2004). Towards the end of the ovarian cycle, secretion of oestradiol by the dominant follicle stimulates the pituitary $\mathrm{LH}$ surge, which induces ovulation (Moenter et al., 1990). Consequently, this study aimed to evaluate the effects of preincubated granulosa cells on steroid hormones production in bovine animals.

Arch. Zootec. 60 (232): 1331-1334. 2011. 


\section{MATERIALS AND METHODS}

This study was conducted at the Department of Animal Physiology, University of Agriculture, Abeokuta, Nigeria. Ten pairs of ovaries from cows were collected from local abattoirs and kept in normal saline for transport to the laboratory.

\section{Preparation of CULTUREMEdiA}

For granulosa cells culture, modified M199 with Earle's salts was used. It was diluted in 1 litre of de- ionized water and $3.36 \mathrm{mM}$ of $\mathrm{NaHCO}_{3}$ was added to the 1 litre TCM-199 solution; $1 \%$ BSA was then added to half of the TCM-199 while 5\% FCS was added to $47.5 \mathrm{ml}$ of TCM- $199 ; 0.8 \%$ of antibiotics was again added to the medium after which 0.2 $\mu \mathrm{m}$ Supor ${ }^{\circledR}$ membrane filter was used to filter the media.

\section{Methodology}

In the laboratory, the ten pairs of ovaries were washed in fresh sterile saline. Ovaries were dried before the granulosa cells recovery from the follicles. All visible follicles were aspirated using 18 " needle. Granulosa cells were separated by centrifuging at $3000 \mathrm{rpm}$ for $10 \mathrm{~min}$. Cell pellet were then mixed thoroughly with the culture

$$
\mathrm{CO}_{2}(\%)
$$

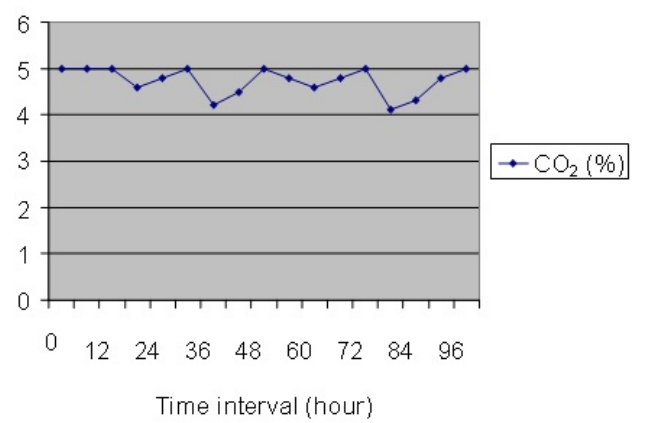

Figure 1. Graphical representation of $\mathrm{CO}_{2}$ regime in the inner chamber of $\mathrm{CO}_{2}$ incubator. (Representación gráfica del régimen de $\mathrm{CO}_{2}$, en la cámara interior del incubador de $\mathrm{CO}_{2}$ ). medium and aliquoted at $50 \mu \mathrm{l} / \mathrm{ml}$ per well into a 24 -well micro plates.

Cultures were incubated at $37^{\circ} \mathrm{C}$ in a $95 \%$ air and $100 \%$ RH. The graphical representation data of $\mathrm{CO}_{2}$ and $\mathrm{RH}$ are presented in figures 1 and 2 . Medium was changed after 2 days of culture and to obtain optimal attachment, cells were maintained in the presence of $10 \%$ FCS for the first 48 hours of culture. Hormonal treatments were maintained for 2 days while on the $3^{\text {rd }}$ day, testosterone $(10 \mathrm{ng} / \mathrm{ml})$ was added as substrate for estradiol production. The experiment was terminated on the $4^{\text {th }}$ day.

\section{DatA COLLECTION}

At the termination of the experiment, culture medium samples were collected for determination of progesterone and estradiol concentrations by Radioimmunoassay method. The design of the experiment includes: (1) additives supplementation i.e. FSH and LH and (2) inclusion levels: (a) 0 $\mathrm{ng} / \mathrm{ml}$ (b) $0.1 \mathrm{ng} / \mathrm{ml}$ (c) $1 \mathrm{ng} / \mathrm{ml}$ (d) $10 \mathrm{ng} / \mathrm{ml}$ and (f) $100 \mathrm{ng} / \mathrm{ml}$ with each treatment replicated 3 times.

\section{STATISTICALANALYSIS}

Data collected were subjected to analysis of variance. Significant means were

\section{$\mathrm{RH}(\%)$}

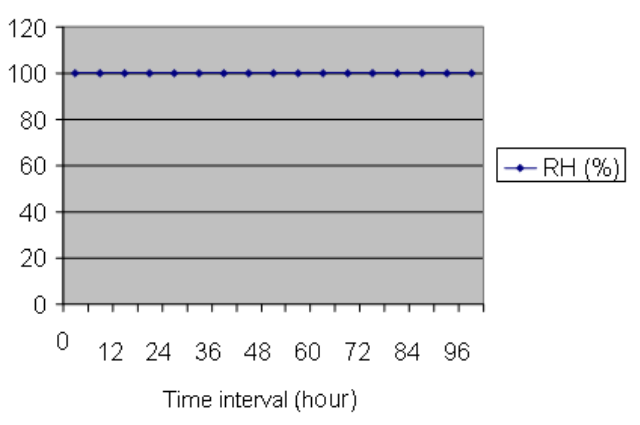

Figure 2. Graphical representation of relative humidity regime in the inner chamber of $\mathrm{CO}_{2}$ incubator. (Representación gráfica del régimen de $\mathrm{HR}$, en la cámara interior del incubador de $\mathrm{CO}_{2}$ ). 
separated using Duncan Multiple Range Test. All data were analyzed using Systat Analytical Computer Package.

\section{RESULTS}

In relation with the effects of FSH on bovine granulosa cells culture in vitro for the production of progesterone and estradiol, there was significant difference among the values of progesterone concentration obtained for different levels of inclusion of FSH (table I). The addition of 10 $\mathrm{ng} / \mathrm{ml}$ of $\mathrm{FSH}$ had the highest value of progesterone. Also there were no significant differences between this value and the progesterone values obtained with other inclusion levels. Estradiol values followed the same pattern of result obtained in the progesterone.

The effects of $\mathrm{LH}$ on bovine granulosa cells culture in vitro for production of progesterone and estradiol are presented in table II. From the table, progesterone values recorded the highest at $100 \mathrm{ng} / \mathrm{ml}$. Although this value was not significantly different from those recorded at $50 \mathrm{ng} / \mathrm{ml}$ and $10 \mathrm{ng} /$ $\mathrm{ml} \mathrm{LH}$ inclusion levels.

Table I. Effects of FSH on bovine granulosa cells culture for progesterone and estradiol producton in vitro. (Efectos de la FSH sobre el cultivo de células de granulosa bovina sobre la producción in vitro de progesterona y estradiol).

\begin{tabular}{ccc}
\hline $\begin{array}{c}\text { FSH inclusion } \\
\text { level }(\mathrm{ng} / \mathrm{ml})\end{array}$ & $\begin{array}{c}\text { Progesterone } \\
(\mathrm{ng} / \mathrm{ml})\end{array}$ & $\begin{array}{c}\text { Estradiol } 17 \beta \\
(\mathrm{pg} / \mathrm{ml})\end{array}$ \\
\hline 0 & $0.88^{\mathrm{d}}$ & $1.41^{\mathrm{d}}$ \\
0.1 & $1.41^{\mathrm{c}}$ & $2.05^{\mathrm{c}}$ \\
1.0 & $2.24^{\mathrm{b}}$ & $3.11^{\mathrm{b}}$ \\
10 & $2.95^{\mathrm{a}}$ & $5.81^{\mathrm{a}}$ \\
50 & $2.94^{\mathrm{a}}$ & $5.69^{\mathrm{a}}$ \\
100 & $2.82^{\mathrm{a}}$ & $5.62^{\mathrm{a}}$ \\
S.E.M. & 0.11 & 0.20 \\
\hline
\end{tabular}

${ }^{a b c d}$ means in the column with different superscript are significant $(p<0.05)$.

\section{DISCUSSION}

Primary cultures of bovine granulosa cells have previously been used to examine a number of events (Amer et al., 2008; Yang and Rajamahendhran, 1998). From the results presented above, there were significant effects of FSH on the progesterone and estradiol production measured and this is in line with the results of Mao et $a l ., 2002)$. It was observed in ths research that an increase in the level of FSH from 10 $\mathrm{ng} / \mathrm{ml}$ upward generates no significant increase in the progesterone production. The inclusion of LH also had significant effects on progesterone and estradiol production. This is a pointer that granulosa cell proliferation is a measure of steroidogenic capacity of cells. Meanwhile, both progesterone and estradiol production reached the highest values when LH was included at $100 \mathrm{ng} / \mathrm{ml}$ in the maturation medium, therefore further increase in the level of inclusion of $\mathrm{LH}$ resulted in no corresponding increase in progesterone and estradiol production. The results obtained in this study is in line with Zuelke and Brackett, 1990 and Saeki et al., 1991. In

Table II. Effects of LH on bovine granulosa cells for progesterone and estradiol production in vitro. (Efectos de la LH sobre células de granulosa bovina para la producción in vitro de progesterona y estradiol).

\begin{tabular}{ccc}
\hline $\begin{array}{c}\text { LH inclusion } \\
\text { level }(\mathrm{ng} / \mathrm{ml})\end{array}$ & $\begin{array}{c}\text { Progesterone } \\
(\mathrm{ng} / \mathrm{ml})\end{array}$ & $\begin{array}{c}\text { Estradiol } 17 \beta \\
(\mathrm{pg} / \mathrm{ml})\end{array}$ \\
\hline 0 & $0.71^{\mathrm{c}}$ & $1.38^{\mathrm{c}}$ \\
0.1 & $0.96^{\mathrm{c}}$ & $1.72^{\mathrm{c}}$ \\
1.0 & $1.29^{\mathrm{b}}$ & $2.69^{\mathrm{b}}$ \\
10 & $1.77^{\mathrm{a}}$ & $3.54^{\mathrm{a}}$ \\
50 & $1.88^{\mathrm{a}}$ & $3.68^{\mathrm{a}}$ \\
100 & $1,99^{\mathrm{a}}$ & $3.27^{\mathrm{a}}$ \\
S.E.M. & 0.08 & 1.14 \\
\hline
\end{tabular}

${ }^{a b c}$ means in the column with different superscript are significant $(p<0.05)$. 


\section{SMITH, OGUNSOLA, LADOKUN AND AJADI}

conclusion, there is necessity for supplementation of hormones into culture medium for successful bovine in vitro maturation and it is suggested further that studies using abattoir ovaries may not be truly representative of the potential of the bovine ovary because mostly aged and underfed animals are slaughtered. Therefore, further studies should be focused on oocytes recovered from animals in good body condition.

\section{REFERENCES}

Amer, H.A., Hegab, A.O. and Zaabal, S.M. 2008. Effects of ovarian morphology on oocyte quantity and quality, granulosa cells, in vitro maturation, and steroid hormone production in buffaloes. Anim. Reprod. Sci., 5: 55-62.

Dierich, A., Sairam, M.R., Monaco, L., Fimia, G.M., Gansmuller, A., LeMeur, M. and Sassone-Corsi, P. 1998. Impairing follicle-stimulating hormone (FSH) signaling in vivo: targeted disruption of the FSH receptor leads to aberrant gametogenesis and hormonal imbalance. PNAS, 95: 1361213617.

Fortune, J.E. 1994. Ovarian follicular growth and development in mammals. Biol. Reprod., 50 225-232.

Ma, X., Dong, Y., Matzuk, M.M. and Kumar, T.R. 2004. Targeted disruption of luteinizing hormone beta-subunit leads to hypogonadism, defects in gonadal steroidogenesis, and infertility. PNAS, 101: 17294-17299.

Mao, J., Guangming, W., Smith, M.F., McCauley, C. Cantely, T.C., Prather, R.S., Didion, B.A. and

\section{ACKNOWLEDGEMENT}

The authors thanked staff of the Laboratory for Physiology and Immunology, Department of Animal Science, Katholeic University of Leuven, Belgium for the Radioimmunoassay analysis. We appreciate the contribution of Prof. O.M. Onagbesan of the Department of Animal Physiology, University of Agriculture, Abeokuta, Nigeria.

Day, B.N. 2002. Effects of culture medium, serum type and various concentrations of $\mathrm{FSH}$ on porcine prenatal follicular development and antrum formation in vitro. Biol. Reprod., 67: 1197-1203.

Moenter, S.M., Caraty, A. and Karsch, F.J. 1990. The estradiol-induced surge of gonadotropinreleasing hormone in the ewe. Endocrinology, 127: $1375-1384$

Saeki, K., Hoshi, M., Leibfried-Rutledge, M.L. and First, N.L. 1991. In vitro fertilization and development of bovine oocytes matured in serum free medium. Biol. Reprod., 44: 256-260.

Yang, M.Y. and Rajamahendran, R. 1998. Effects of gonadotropins and insulin-like growth factorsI and -II on in vitro steroid production by bovine granulosa cells. Can. J. Anim. Sci., 78: 587597.

Zuelke, K.A. and Brackett, B.G. 1990. Luteinizing hormone-enhanced in vitro maturation of bovine oocyte with and without protein supplementation. Biol. Reprod., 43: 784-787. 